\title{
HYDRAULIC PEROFORMNACE OF FAUCET AERATOR AS WATER SAVING DEVICE AND SUGGESTIONS FOR ITS IMPROVEMENTS
}

\author{
Umesh $V^{1}$, Nagaraj Sitaram ${ }^{2}$ \\ ${ }^{\text {I}}$ Professor, Department of Civil Engineering, SJB Institute of Technology, Uttarahalli Main Road, Kengeri, \\ Bangalore-60, Karnataka, India \\ ${ }^{2}$ Professor, Department of Civil Engineering, SJB Institute of Technology, Uttarahalli Main Road, Kengeri, \\ Bangalore-60, Karnataka, India
}

\begin{abstract}
Conserving both water and energy with water-efficient technologies is extremely beneficial to the environment. Water conservation is defined as any action that reduces the amount of water withdrawn from water supply sources, reduces consumptive use, reduces the loss or waste of water, improves the efficiency of water use, increases recycling and reuse of water, or prevents the pollution of water. The faucet aerators used in kitchen and W/C taps regulate and reduce the water consumption by the process of aeration. This helps to reduce the usage of water, results in non-splash flow hence these fittings into water taps acts as water saving devices. These devices (faucet aerators) are simple to install and cost effective (Cost ranges between Rs. 150Rs. 450) for normal usage at domestic and industrial installations. If we use faucet aerators and shower heads, we can save money on our heating and water bills. Previous works have revealed that users' requirements include temperature stability, adequate water volume and its distribution. All of which are substantially controlled by the faucet aerators. The experiments were carried out at the Fluid Mechanics Laboratory, School of Engineering and Technology, Jain University, Bangalore, wherein the hydraulic test rig was installed for conducting the performance test on aerators. The main aim is to conserve the water by usage of faucet aerators; to assess the hydraulic performance of existing faucet aerators and to determine the most suitable type.
\end{abstract}

Keywords: Air, water, conservation, hydraulic, performance, geometry, pipe, flow rate, pressure, pipeline

\section{INTRODUCTION}

Aerators reduce the water coming through the faucets by mixing it with air. The aerator acts as a sieve, sending a single flow of water into many tiny streams. This introduces the air into the water flow. Since there is less space for the water to flow through, the water flow is reduced. The wastage of water must be avoided by giving encouragement for the usage of water-saving devices such as aerators, [A. Mounder, 1993] showerheads in hotels, residential and public toilets.

The aim is to reduce the water input (up to 50\%) without sacrificing the consumer satisfaction. The hydraulic performances of commercial aerators (using experimental and numerical methods) as water-saving devices are determined and suggestions are made for improvement in water-saving devices based on hydraulic (line pressure, flow-rates) and geometrical parameters (reducing or increasing mesh size). Standard faucet aerators being flow control aerators are small in size but can create significant water savings. The Water Management can be divided into two groups:-

- $\quad$ System Users - Household, Industry, Agriculture.

- System Operators - Municipal, State \& Local Government and Private Suppliers.

In the present day scenario, water conservation is a necessity. This is done by minimizing the water input.
The faucet aerators govern the flow rate less than 10 litres/ min allowing the entrainment of air thereby result in fine droplets. Correspondingly the volume of water used is reduced. The low flow device results in water savings of $20 \%$ to $50 \%$ of the normal usage.

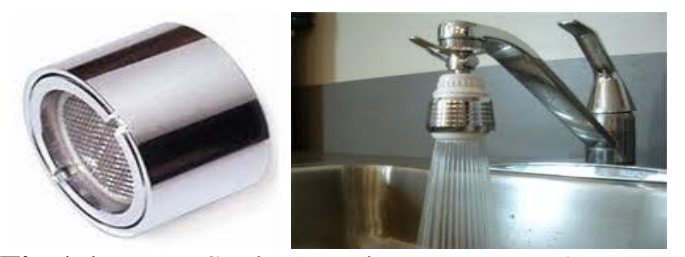

Fig 1.1 Water Saving Devices - Faucet Aerator

Aerators compress the water flow into a higher-pressure discharge than regular faucets. They also introduce air bubbles into the water, making it feel like there is a larger water flow. However, the water pressure is maintained, which is why most people don't notice a difference in the amount of water coming out of an aerated faucet. Since the water is somewhat compacted by an aerator, it may even increase the water pressure in a faucet that typically has lighter-than-normal water pressure.

Some aerators now come with flow restrictors [Andrew P. Jones1993]. Essentially, this is a temporary "off" switch. These are particularly handy when we are doing dishes. A restrictor will turn the water off at the nozzle with a quick flip of a lever. When we need the water, another quick flip 
starts it flowing again. It's one more feature to help us save water [Sandra, 1982].

Aerators can be used in residential and commercial buildings W/C and bath as well as in public toilets [Cortez.M, 1993] which are installed in flushing systems, taps, shower-heads, etc.[Swaffield,1988]

\section{NEED FOR THE STUDY}

Laminar flow controls deliver a precise volume of water at faucets, showerheads, and hose outlets. Unlike conventional water-saving fixtures that deliver varying flow rates in response to varying line pressure [NAHB,1992]. American Water Works Association has highlighted the importance of water saving devices $[3,7,9,10,18,21]$

During 1994-1997, the New York City Department of Environmental Protection (DEP) has installed water-saving devices in faucets and showerheads as a part of the water conservation project. An important evaluation of project results in multi-family buildings found an average reduction in water use up to $29 \%$ or 315 Liters per apartment per day in Saudi Arabia [2,8,20,22] experiments have been carried to investigate effective water saving technologies using faucet aerators, low plumbing fixtures.

European Standard for faucet aerators was given by NEOPEARL, Inc.171 Mattatuck Heights Waterbury, CT 06705, in 2000 and is as given in Chart 1. Bassam Hasbini (2003) and T.Kondo (2006) has carried out experimental study on different types of faucet aerator and highlighted the importance of aerator geometry, stop valve on water and energy saving

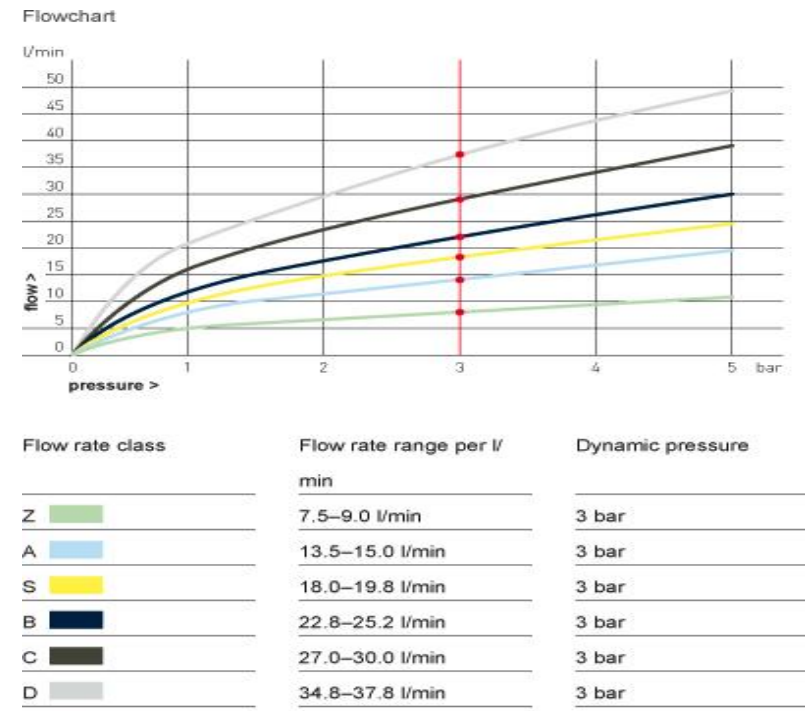

In our country a limited study is carried-out on "watersaving devices" mainly carried by few leading research institutions in the country like FCRI, Pallakad, and CWRDM, Kozhikode (on sprinklers). M/S Parryware and Hindware companies have brought out several water-saving fixtures in the market. They have suggested the following measures along with use of water saving devices:
- Installing high-pressure, low volume nozzles on spray washers;

- Using fogging nozzles to cool product;

- Replacement of high volume hoses with high-pressure, low volume flush toilet.

Ranganathan (2007) carried a limited study on Water Efficient Faucets and Fixtures used in Home. The Critical dimensions for water efficient flushing are obtained based on computer simulation techniques.

All the above study does not clarify the mechanism of water saving in a faucet aerator. It has also not suggested any governing parameters responsible for water saving in these devices. The present study aims at the following:

- To determine the water-saving of existing faucet aerators based on experimental investigations.

- To verify their claim for water saving.

- To suggest modifications in design to further improve their performance.

\section{FAUCET AERATOR PARTS}

The typical parts of an existing commercial faucet aerator are: Steel body, Water-Inlet, Wire meshes \& other internal geometry, restrictions (for stream-lining of flow). The important geometric parameters are, Air-Inlet (for mixing air with water and reduce the flow rate), and number of Plastic Restrictors (function is to save the water by distributing the flow).
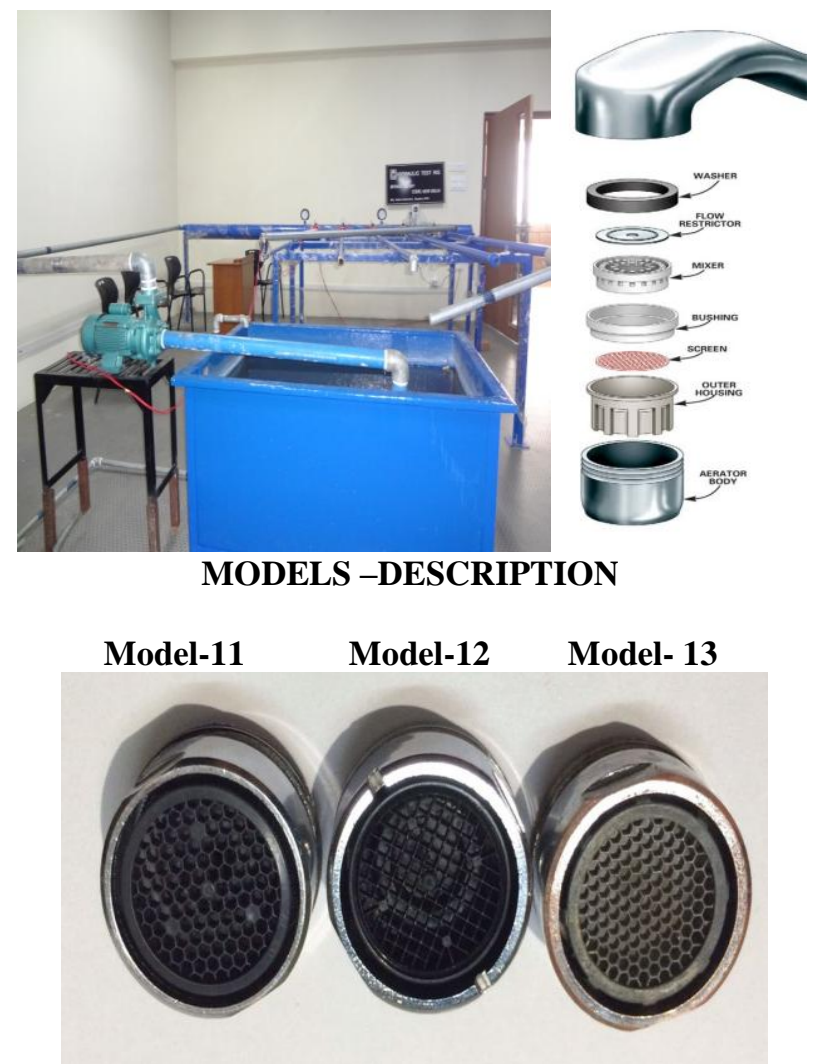

Fig. 3.1 Hydraulic test rig and Parts of a Faucet Aerator 
Table-1: Description of Faucet Aerator Models

\begin{tabular}{|l|l|l|l|l|}
\hline $\begin{array}{l}\text { Aerator } \\
\text { types }\end{array}$ & $\begin{array}{l}\text { No. } \\
\text { meshes }\end{array}$ & $\begin{array}{l}\text { AREA OF } \\
\text { AIR } \\
\text { PASSAGE } \\
\text { (Cm) }^{\mathbf{2}}\end{array}$ & $\begin{array}{l}\text { AREA } \\
\text { OF } \\
\text { FLOW } \\
\text { (Cm) }\end{array}$ & $\begin{array}{l}\text { BLOC } \\
\text { KAGE } \\
(\%)\end{array}$ \\
$\begin{array}{l}\text { Pipe } \\
\text { Area }\end{array}$ \\
\hline $\begin{array}{l}\text { Mode-11 } \\
\text { (Parryware) }\end{array}$ & $\begin{array}{l}2 \\
\text { (dissimilar) }\end{array}$ & 0.691 & 1.1 & 0.134 \\
\hline $\begin{array}{l}\text { Mode-12 } \\
\text { (Jaguar) }\end{array}$ & 1 & 0.628 & 1.21 & 0.048 \\
\hline $\begin{array}{l}\text { Mode-13 } \\
\text { (Ess-Ess) }\end{array}$ & $\begin{array}{l}2 \\
\text { (dissimilar) }\end{array}$ & 0.628 & 0.95 & 0.222 \\
\hline
\end{tabular}

\subsection{Experimental Set-Up \& Methodology}

The hydraulic-rig performance tests of 4 different types of aerators were conducted using the hydraulic-test rig at School of Engineering \& Technology, Jain University, Bangalore at different pressures-manifold pressure and line pressure $\left(0.8,1.0,1.2 \mathrm{~kg} / \mathrm{cm}^{2}\right)$. The time required in seconds(s) for a flow of ten (10) litres (1) was calculated for each sector angle of flow regulator for the $12.5 \mathrm{~mm}$ to $19.05 \mathrm{~mm}$ pipe line size for three different line pressures. The flow rate is computed. Experiments are carried out with $\&$ without faucet aerators to estimate the water savings for three models for a given line pressure, and temperature. The percentage of water savings is calculated for the available models. The most efficient model of faucet aerator determination of the most efficient model aerator is identified.

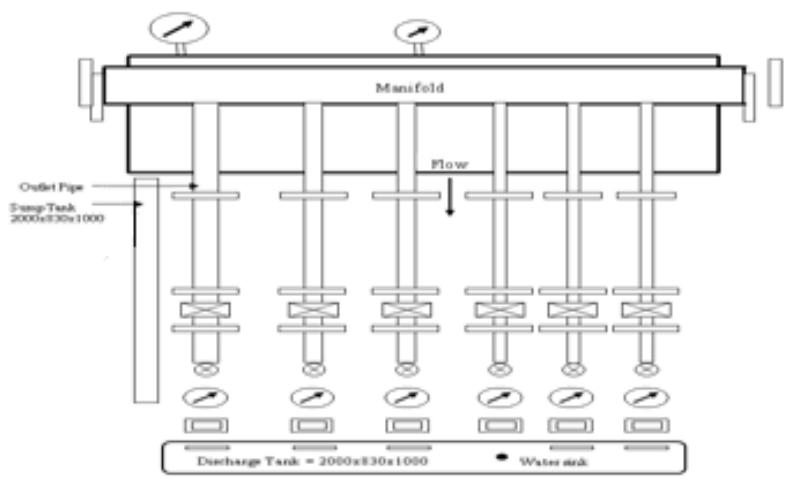

Fig. 3.1 Experimental Set-Up

\section{RESULTS AND DISCUSSIONS}

The majority of the faucet aerators tested obeyed a simple pressure-flow relationship with flow being proportional to the square root of the internal pressure at the showerhead. $Q=k \sqrt{\Delta P}$, where $\mathrm{Q}=$ flow rate in $\mathrm{cm}^{3} / \mathrm{sec}$, $\Delta \mathrm{P}=$ Pressure difference $\left(\mathrm{kg} / \mathrm{cm}^{2}\right)$ in the faucet aerator and ' $\mathrm{k}$ ' is a form of discharge coefficient. This is in accordance with the theory for turbulent flow through a constriction. The value of the constant ' $\mathrm{k}$ ' will depend on the nature of the constriction (and also on the units chosen for Q and P). The collected data is analysed to determine the water saving efficiency of the three different types of faucet aerators at different flow rates. To obtain the desired results, the line pressures and line size is also varied. Following are the variables identified in a faucet aerator:-

MODEL- 1 (12.7 mm pipe)

Table-2: Discharge for different line pressures

\begin{tabular}{|l|l|l|l|l|l|}
\hline $\begin{array}{l}\mathbf{Q} \\
\left(\mathbf{C m}^{3} / \mathbf{s}\right)\end{array}$ & $\begin{array}{l}\mathbf{Q}_{\mathbf{0}} \\
\left(\mathbf{c m}^{3} / \mathbf{s}\right)\end{array}$ & $\left(\mathbf{Q} / \mathbf{Q}_{\mathbf{0}}\right)^{\mathbf{2}}$ & $\mathbf{R}_{\mathbf{e}}$ & $\mathbf{R}_{\mathbf{e} \mathbf{0}}$ & $\mathbf{R}_{\mathbf{e} 0} / \mathbf{R}_{\mathbf{e}}$ \\
\hline LINE PRESSURE & $\mathbf{1 . 2}\left(\mathbf{k g} / \mathbf{c m}^{\mathbf{2}}\right)$ & \multicolumn{3}{l|}{} \\
\hline 153.84 & 338.98 & 0.205 & 18761 & 41338 & 2.203 \\
\hline 149.25 & 322.5 & 0.213 & 18201 & 39329 & 2.160 \\
\hline 144.92 & 256.4 & 0.319 & 17674 & 31348 & 1.773 \\
\hline 126.58 & 170.9 & 0.547 & 15436 & 23841 & 1.305 \\
\hline 94.33 & 111.11 & 0.719 & 11504 & 13550 & 1.177 \\
\hline 18.08 & 32.73 & 0.304 & 2205 & 3991 & 1.809 \\
\hline LINE PRESSURE & $\mathbf{1 . 0}\left(\mathbf{k g} / \mathbf{c m}^{\mathbf{2}}\right)$ & & \\
\hline 151.5 & 135.13 & 0.795 & 18937 & 17971 & 0.949 \\
\hline 151.5 & 132.74 & 0.772 & 18937 & 18160 & 0.959 \\
\hline 151.5 & 128.2 & 0.715 & 18937 & 18009 & 0.951 \\
\hline 147 & 116.278 & 0.624 & 18373 & 15855 & 0.863 \\
\hline 135 & 87.719 & 0.414 & 16875 & 11272 & 0.668 \\
\hline 104 & 37.81 & 0.3025 & 13000 & 2990 & 0.23 \\
\hline LINE PRESSURE & $\mathbf{0 . 8}\left(\mathbf{k g} / \mathbf{c m}^{2}\right)$ & & \\
\hline 138.8 & 263.15 & 0.277 & 17351 & 32092 & 1.849 \\
\hline 135 & 238.09 & 0.321 & 16875 & 29036 & 1.721 \\
\hline 131.5 & 230 & 0.327 & 16430 & 28000 & 1.709 \\
\hline 128 & 208.33 & 0.377 & 15998 & 25406 & 1.588 \\
\hline 119 & 166.67 & 0.860 & 14875 & 20325 & 1.366 \\
\hline 86 & 100 & 0.384 & 10748 & 12195 & 1.135 \\
\hline \multicolumn{7}{|l|}{} \\
\hline
\end{tabular}

\section{Where}

$\mathrm{Re}$ - represents Reynolds number with water saving device $\mathrm{Re}_{0}$-represents Reynolds number without water saving devices

Q- Discharge with water saving device.

$\mathrm{Q}_{0}$ - Discharge without water saving device.

Figure 5 and Figure 6 clearly shows that $12.7 \mathrm{~mm}$ pipeline is more effective as compared to $19.05 \mathrm{~mm}$ pipeline for faucet aerator as water saving devices. The maximum value of $\%$ water saving of $55 \%$ is reported for $12.7 \mathrm{~mm}$ pipeline as against $32 \%$ in $19.05 \mathrm{~mm}$ pipeline.

Hence the mixing efficiency of air with water has more effect in $12.7 \mathrm{~mm}$ pipeline for models of faucet aerators.

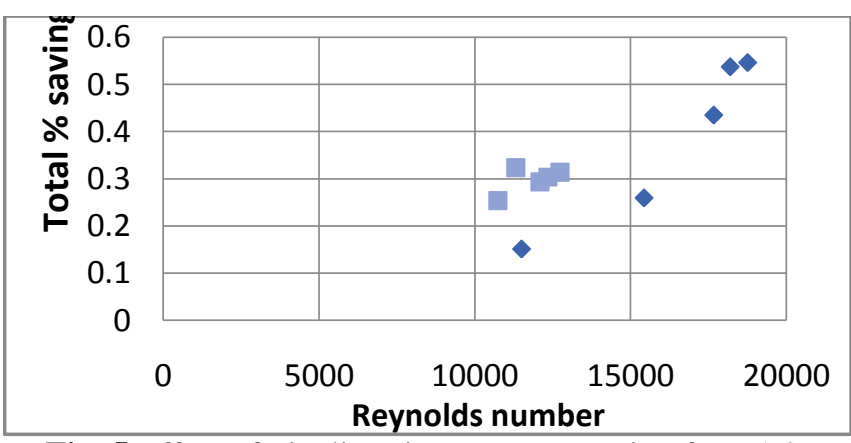

Fig. 5 Effect of Pipeline size on water saving for a 1.2 $\mathrm{kg} / \mathrm{Cm}^{2}$ line pressure 
- For $19.05 \mathrm{~mm}$ pipe

- $\quad$ For $12.7 \mathrm{~mm}$ pipe

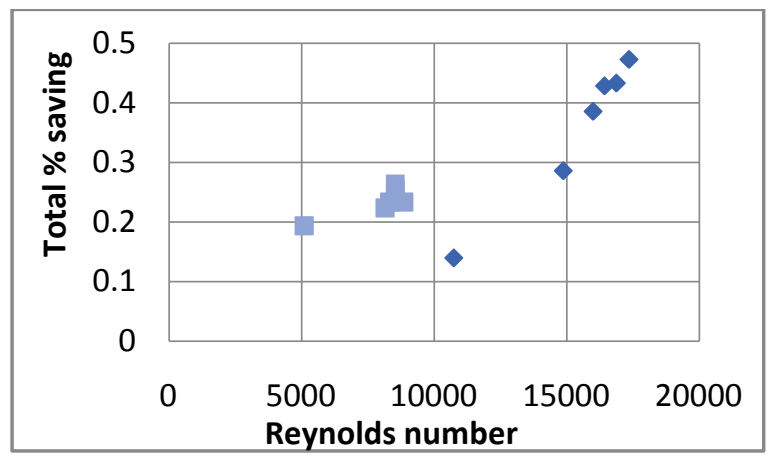

Fig. 6 Effect of Pipeline size on water saving for a 0.8 $\mathrm{kg} / \mathrm{Cm}^{2}$ line pressure

\section{CONCLUSIONS}

- Based on the experimental results of the 3 aerators of different geometrical configuration which are operated on similar hydraulic conditions (for a given pipe size) it is observed that water saving is relatively more with 2-dissimilar mesh combination as compared to single mesh or 3-mesh type.

- The length of air passage need to be equal to diameter of aerator for maximum saving of water for a given line pressure and flow rate.

- The highest water saving is $47 \%$ for model number-2 (M/s ESS-ESS Gurgaon) when air mixing is maximum at $22.6 \%$

- Since the Aerator-2 shows the maximum water saving with the length of air passage equal to $6.5 \mathrm{~mm}$, therefore for improvising new designs the length of the air passage should be comparatively reduced.

- The graphical relationship is obtained for discharge with saving devices $(\mathrm{Q})$ with main flow rate $\left(\mathrm{Q}_{0}\right)$ for different line pressures (1.2bar, 1.0bar, 0.8bar).

- The wire mesh of aerator should not occupy the entire portion of the flow area. For maximum saving of water the preferred ratio of pores in aerator to the total flow area should lie between 0.85-0.98.

- The mesh should have pores bearing the same dimensions to obtain a high efficiency.

- The maximum line pressure with maximum air entrainment can effectively bring about the greatest ability to save water.

\section{ACKNOWLEDGEMENTS}

The authors express their sincere thanks to Council for Scientific \& Industrial Research, New-Delhi for funding the research project.

\section{REFERENCES}

[1] Maunder, Awash with profit opportunities, EngineeringManagement journal, vol. 9(4), p:166170,1993

[2] Al-Ibrahim, A.A. (1990 Water use in Saudi Arabia: Problems and Policy Implications. Journal of water resources planning and management. Vol. 116, No.3, p: 375-314

[3] American Water Works Association, 1995. Cleaner Water Through Conservation, Technical Report EPA 841-B-95-002.4

[4] Andrew P.Jones, 1993.High efficiency Shower heads and Faucets, Technical Report Water Efficiency TechnologyReport\#2, Rocky Mountain Institute Water Program,Snowmass.9

[5] Cortez M., and Petronilo, 1993. Low Consumption Toilets and Other Domestic Water Saving Devices Evaluation, Proceedings of Conserve 93; The New Water Agenda, Las Vegas, p:7-10.7

[6] Donald E. Agthe and R. Bruce Billings, Water-Price Effect on Residential and Apartment Low-Flow Fixtures, Journal of Water Resources Planning and Management, p: 20-23, 1996

[7] Donna Pacetti, 1993. Conservation: Uniting Energy and Water Utilities, Technical Report, American Water Works Association.8

[8] Dr. Bassam Hasbini, Dr. Yasmeen Al Lawati "Water saving Technologies study outcome for the Ministry of Regional Municipalities, Environment \& Water Resources in Oman" 2003

[9] Edward R. Osann, and John E. Young, 1998. Saving Water, Saving Dollars: Efficient Plumbing Products and the Protection of America's Waters, Technical Report, American council for an Energy-Efficient Economy, Washington, DC, USA.6

[10] Ellen Pinnes, 1993. Water Conservation: An Overview, Technical Report, American Water Works Association.

[11] European Standard for Faucet Aerators were given by NEOPERL, Inc.171 Mattatuck Heights Waterbury, CT 06705, USA in 2000

[12] Laminar flow controls deliver a precise volume of water at faucets, showerheads, and house outlets, NAHB Research Center, Upper Marlboro, Maryland, 1992

[13] M/s Grohe. AG Hemer Germany , Use of CFD to design a Faucet with an integrated thermostat as reported by CFD Bulletin on Application in embedding the flow edited by Chris Watson-August 2007

[14] R.A. Alkhaddar, D. Phipps, R. Morgan, B. Karci and J. Hordesseux "Saving water in showers" Sensors and their Applications XIV (SENSORS07) IOP Publishing Journal of Physics: Conference Series 76-012064(2007)

[15] Ranganathan K E Managing Director, Parryware Roca Pvt. Limited Water Efficient Faucets and Fixtures in Home - Critical dimensions for water efficient flushing are used based on CFD simulation 2007. 
[16] Sandra L. Postal, "Flow reduction: Method, Analysis procedures, examples, Resource Economist, INTASA, Inc, Menlo park, California USA p 8190,1982

[17] Swaffield and R.H.M.Wakein, "water conversation: the impact of design, development and site appraisal of a low-volume flush toilet", pp 176-188, DIVISION OF BUILDING TECHNOLOGY , BRUNEL UNIVERSITY , SCOTLAND, 1988

[18] Thomas M. Babcock, 1990. The World's Greatest Water-SavingDevice: Evaluating Plumbing Retrofit Devices, Proceedings of Conserve 90 The National Conference and Exposition Offering Water Supply Solutions for the 1990s, Phoenix, American Water Works Association. p:173-177.10

[19] US Government Printing Office, 1977. Water Conservation Devices: Residential Water Conservation, Technical Report, Superintendent of Documents, Washington.13

[20] Viwanathan, M. N., Water Conservation Strategies for the State of Kuwait, Proceedings of Conserv 96: Responsible Water Stewardship, p:7-11, 1995

[21] William E. Sharpe, 1978. Water and Energy Conservation With Bathing Shower Flow Controls, J. American Water Works Association, p:93-97.12

[22] Yousef A Al-Rumikhani, WSTA 5th Gulf Water Conference, March 2001, Doha, Quatar.

\section{BIOGRAPHIES}

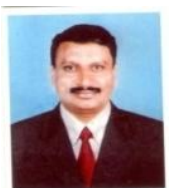

Umesh.V, Professor, Department of Civil Engineering SJB Institute of Technology, Bangalore, Karnataka, India - 560060.

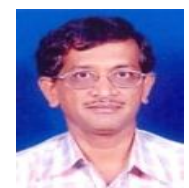

Dr. Nagaraj Sitaram Professor, Department of Civil Engineering, SJB Institute of Technology, Bangalore, Karnataka, India 560060. 